AL IBTIDA: JURNAL PENDIDIKAN GURU MI (2018) Vol 5 (2) : 145-158

DOI: http://dx.doi.org/ 10.24235/al.ibtida.snj.v5i2.2788

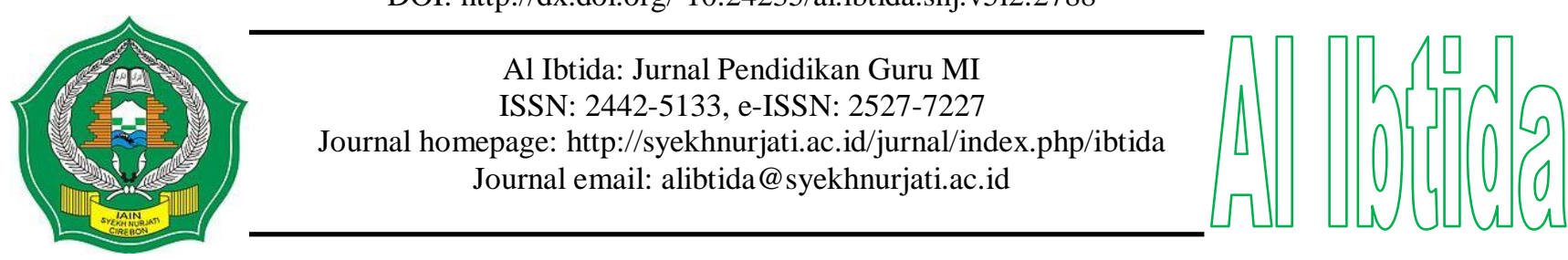

\title{
Pengembangan Bahan Ajar DELIKAN Tematik Berbasis Multimedia Interaktif Untuk Siswa Sekolah Dasar di Kota Kediri
}

\author{
Bagus Amirul Mukmin* \\ *Program Studi Pendidikan Guru Sekolah Dasar, Fakultas Keguruan dan Ilmu Pendidikan, \\ Universitas Nusantara PGRI Kediri \\ Email: bagus@unpkediri.ac.id \\ Farida Nurlaila Zunaidah** \\ ** Program Studi Pendidikan Guru Sekolah Dasar, Fakultas Keguruan dan Ilmu Pendidikan, \\ Universitas Nusantara PGRI Kediri \\ Email: farida@unpkediri.ac.id
}

Received 27 June 2018; Received in revised form: 01 October 2018; Accepted 02 October 2018

Publish Online: 28 October 2018

\begin{abstract}
Abstrak
Proses pembelajaran yang dilaksanakan di sekolah dasar saat ini belum memanfaatkan teknologi secara maksimal, sehingga proses pembelajaran kurang inovatif dan menarik. Hal ini salah satunya dikarenakan ketersediaan bahan ajar tematik berbasis teknologi seperti multimedia interaktif yang ada di sekolah dasar masih kurang, sehingga berdampak pada hasil belajar siswa yang masih rendah. Penelitian ini bertujuan untuk mengembangkan bahan ajar DELIKAN (Dengar, Lihat, Kerjakan) tematik berbasis multimedia interaktif yang valid, praktis, dan efektif untuk siswa sekolah dasar. Bahan ajar DELIKAN tematik berbasis multimedia interaktif dipilih untuk memaksimalkan fasilitas teknologi yang sudah tersedia dan memberikan inovasi pembelajaran yang efektif untuk siswa. Model yang digunakan dalam penelitian pengembangan ini adalah modifikasi model Borg \& Gall dan Lee \& Owen dengan tahapan penelitian dan pengumpulan data, perencanaan, pengembangan produk, validasi desain, revisi desain, uji coba produk, revisi produk, dan uji coba pemakaian. Berdasarkan hasil uji coba produk, bahan ajar DELIKAN tematik berbasis multimedia interaktif menurut ahli materi memperoleh skor prosentase validitas sebesar 94\%, ahli multimedia 83\%, dan ahli bahasa $80 \%$ dengan kategori valid. Berdasarkan respon kepraktisan siswa, produk ini memperoleh skor $95 \%$ dan $96 \%$ berdasarkan respon kepraktisan guru. Sedangkan untuk keefektifan produk ini mencapai $85 \%$ dengan kategori sangat efektif. Berdasarkan data tersebut dapat disimpulkan bahwa bahan ajar DELIKAN tematik berbasis multimedia interaktif valid, praktis, dan efektif.
\end{abstract}

Kata kunci: pengembangan bahan ajar, delikan, tematik, multimedia interaktif 


\begin{abstract}
The learning process that carried out in elementary schools at this time has not utilized technology optimally, so the learning process is less innovative and interesting. This is partly because the availability of technology-based thematic teaching materials such as interactive multimedia in elementary schools is still lacking, which has an impact on student learning outcomes that are still low. This research aims to develop teaching materials of DELIKAN (Dengar, Lihat, Kerjakan) for thematic learning that are based on interactive multimedia on valid, practical, and effective for elementary students. Thematic teaching material of DELIKAN based on interactive multimedia is choosen to maximises available technology facilities and provides innovation of effective learning for students. Model used in this development research is modifying model from Borg \& Gall and Lee \& Owen which stages are research and data collection, planning, product development, design validation, design revision, product trials, product revision, and usage trials. Based on the product test result, the thematic teaching material of DELIKAN based on interactive multimedia obtained a score $94 \%$ of percent validity according to material expert, $83 \%$ from multimedia expert, and $80 \%$ from language expert with quite valid category. Based on students' practicality, this product got a score $95 \%$ and $96 \%$ based on teacher practicality. Whereas for the effectiveness, this product reaches $85 \%$ with very effective category. Based on those data, it can be conclude that thematic teaching material of DELIKAN based on interactive multimedia is valid, practical, and effective.
\end{abstract}

Keywords: development of teaching materials, delikan, thematic, interactive multimedia

\title{
PENDAHULUAN
}

Pada abad 21 manusia mulai tidak bisa terlepas dari dunia digital, salah satunya kemajuan teknologi saat ini yang memberikan inovasi-inovasi baru untuk membantu memudahkan manusia dalam menjalankan pekerjaannya. Kemajuan tersebut juga berpengaruh pada dunia pendidikan baik secara langsung maupun tidak langsung. Baik itu sistem pembelajarannya, bahan ajar, model, metode, maupun media pembelajaran yang digunakan di dunia pendidikan. Dunia pendidikan, khususnya di sekolah-sekolah, perkembangan teknologi ini ditandai dengan semakin tersedianya fasilitas pembelajaran yang berbasis teknologi, seperti komputer atau laptop (Arief, 2013). Fasilitas tersebut juga memberikan manfaat serta mampu meningkatkan kopetensi yang dimiliki oleh guru. Seperti yang dikemukakan oleh (Hardianto, 2013) fasilitas teknologi tersebut juga dapat membantu guru dalam memudahkan pembelajaran, memotivasi dan mengakselerasi belajar siswa. Fasilitas tersebut tidak akan bermanfaat tanpa ada bahan ajar yang mampu berkontribusi untuk mendukung fasilitas komputer yang ada di sekolah. Menurut (Komalasari, 2010) menyatakan bahwa bahan ajar yang baik yaitu penyajiannya menarik, menantang, dan bervariasi sehingga siswa benar-benar termotivasi untuk mempelajarinya.

Bahan ajar yang mampu mendukung fasilitas pembelajaran berbasis teknologi masih sangat sedikit seperti multimedia interaktif. Komputer dan laptop banyak ditemui di sekolah kota-kota besar. Salah satunya di kota Kediri seperti Mrican 3 tetapi fasilitas tersebut jarang 
digunakan dalam pembelajaran karena belum adanya bahan ajar yang berbasis tematik yang mendukung fasilitas komputer yang ada di sekolah. Sehingga komputer tersebut hanya digunakan untuk pelajaran komputer dan ekstra kurikuler sekolah. Padahal jika dirancang secara khusus fasilitas tersebut bisa memberi kontribusi yang efektif bagi pembelajaran dan bisa membantu siswa meraih potensi tertinggi mereka (Smaldino, 2011). Fasilitas teknologi tersebut juga dapat membantu guru dalam memudahkan pembelajaran, memotivasi dan mengakselerasi belajar siswa (Hardianto, 2013).

Berdasarkan wawancara yang dilakukan dengan kepala sekolah SDN Mrican 3, mengungkapkan bahwa fasilitas komputer yang ada di sekolah belum mampu dimanfaatkan dengan maksimal. Permasalahannya adalah belum tersedianya bahan ajar tematik berupa multimedia interaktif untuk digunakan dalam pembelajaran dengan teknologi komputer. Pada akhirnya pembelajaran yang ada di sekolah kurang inovatif. Akibatnya berdampak pada hasil belajar siswa yang tuntas di atas KKM (75) hanya mencapai 65\%. Jika dibiarkan lama kelamaan permasalahan ini akan berdampak buruk pada kegiatan pembelajaran di sekolah.

Berdasarkan penelitian yang pernah dilakukan oleh (Nopriyanti, 2015) menyatakan bahwa produk multimedia pembelajaran interaktif efektif meningkatkan hasil belajar siswa. Dibuktikan dengan hasil bejara pada saat pretest nilai rata-rata hanya 63, sedangkan hasil ratarata potest siswa setelah menggunakan produk tersebut menigkat menjadi 78 . Begitu pula dengan hasil penelitian yang dilakukan Fibriani, Damris \& Risnita (2014) mengungkapkan bahwa hasil belajar dapat ditingkatkan dengan penggunaan multimedia interaktif pada pembelajaran. Pernyataan tersebut dibuktikan oleh nilai tes evaluasi yang menunjukkan persentase rerata nilai sebesar $86,06 \%$ dengan kriteria sangat efektif. Penggunaan multimedia interaktif dengan pembelajaran berdasarkan masalah dapat meningkatkan hasil belajar kognitif. Selain itu multimedia interaktif juga menarik untuk siswa dalam belajar seperti hasil penelitian (Ali, 2009) yang menyatakan bahwa respon mahasiswa terhadap produk media pembelajaran interaktif ini sangat baik untuk mendukung belajar mandiri dibuktikan dengan sekor rata-rata penilaian 3,23 pada skala liket.

Berdasarkan paparan di atas, penulis tertarik untuk mengembangkan bahan ajar DELIKAN (Dengar, Lihat, Kerjakan) tematik berbasis multimedia interaktif untuk siswa SD yang valid, efektif, dan praktis untuk siswa. Diharapkan, informasi yang diperoleh dari penelitian ini dapat menjadi referensi praktis penelitian berikutnya untuk mengembangkan bahan ajar sejenis pada materi yang lebih luas dengan orientasi model inovatif lainnya.

\section{METODE PENELITIAN}

Model penelitian pengembangan yang digunakan dalam penelitian ini adalah modifikasi model Borg \& Gall dan Lee \& Owen (2004). Kedua model di atas dimodifikasi dan disinergikan untuk saling melengkapi keterbatasan dan mengoptimalkan kelebihan masing-masing model. 
Model Borg \& Gall menekankan pada penelitiannya, sedangkan model Lee \& Owen lebih spesifik pada pengembangan multimedia interaktifnya. dengan tahapan penelitian dan pengumpulan data, perencanaan, pengembangan produk, validasi desain, revisi desain, uji coba produk, revisi produk, dan uji coba pemakaian.

Teknik analisis data yang digunakan pada penelitian ini adalah analisis data deskriptif kuantitatif dan analisis data deskriptif kualitatif. Analisis kuantitatif digunakan untuk mengolah data dari angket dan lembar tes dan analisis deskriptif untuk mengolah data berupa respon (saran/ tanggapan/ kritik). Data deskriptif kuantitatif dan deskriptif kualitatif tersebut diperoleh dari tiga jenis data, yaitu data validitas, kepraktisan, dan keefektifan. Suatu perangkat komputer pendukung pembelajaran (multimedia) dikatakan memiliki kualitas yang tinggi jika mencakup karakteristik validitas (validity), kepraktisan (practicality), dan keefektifan (effectiveness).

\section{HASIL DAN PEMBAHASAN}

\section{A. Spesifikasi Produk Yang Dihasilkan}

Hasil luaran yang dicapai dalam penelitian pengembangan ini adalah produk bahan ajar DELIKAN tematik berbasis multimedia interaktif. Dimana produk ini memiliki ciri 3 langkah dalam penggunaannya yaitu dengar, lihat, dan kerjakan. Tahap (1) guru menjelaskan petunjuk penggunaan produk dimana siswa diminta untuk mendengarkan penjelasan tersebut agar bisa menjalankan produk dengan baik. Tahap (2) siswa diminta untuk mengoprasikan produk dengan cara melihat petunjuk, indikator, dan materi dengan seksama. Tahap ke (3) siswa diminta mengerjakan quis sebagai tolok ukur kemampuan kognitif mereka setelah melewati tahapan 1 dan 2.

Pengembangan bahan ajar dalam penelitian ini diujicobakan pada beberapa subjek yaitu ahli desain multimedia, ahli materi, ahli bahasa, guru kelas, dan siswa SD kelas V. Bahan ajar ini bersifat interaktif karena memungkinkan interaksi siswa. Siswa dapat melakukan perintah kepada bahan ajar dan bahan ajar dapat memberikan balikan kepada siswa. Spesifik komponen multimedia terdiri dari sampul, menu-menu, tombol-tombol, video, pengisi suara, audio, gambar, materi, bentuk tulisan, warna, soal quis, tokoh anak SD, dan petunjuk penggunaan. Adapun salah satu contoh gambar bahan ajar DELIKAN tematik berbasis multimedia interaktif sebagai berikut. 


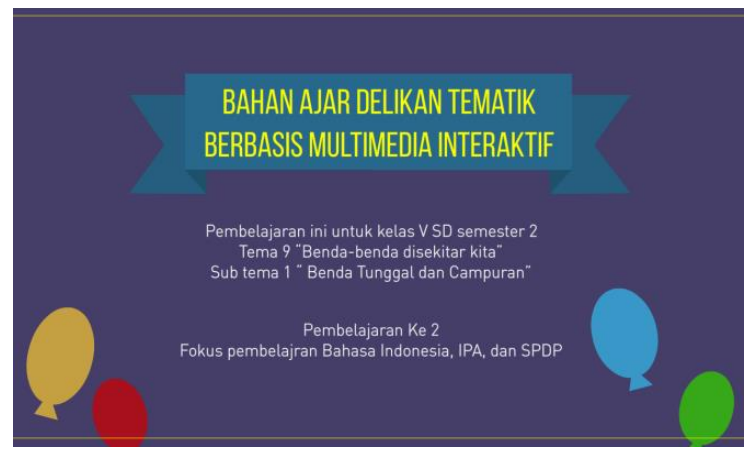

Gambar 1. Tampilan pembuka produk

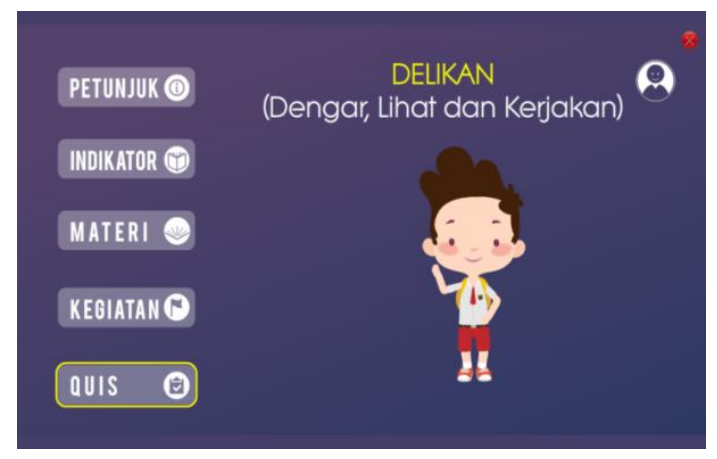

Gambar 2. Tampilan menu utama

\section{B. Hasil Validasi Bahan Ajar Delikan}

Untuk mengetahui validitas bahan ajar DELIKAN tematik berbasis multimedia interaktif yang dikembangkan dilakukan validasi oleh 3 orang validator, yakni validator ahli materi, ahli desain multimedia, dan ahli bahasa. Proses validasi pertama kali dilakukan pada ahli materi pembelajaran IPA SD yaitu bapak Sutrisno Sahari, M.Pd. Adapun hasil validasi ahli materi pembelajaran IPA SD dapat dilihat pada Tabel 1.

Tabel 1. Hasil Validasi Ahli Materi Pembelajaran IPA SD

\begin{tabular}{lllll}
\hline No. & Aspek yang Divalidasi & Nomor Butir & $\mathbf{X}$ & Y \\
\hline 1 & Kelengkapan materi & 1 & 4 & 4 \\
\hline \multirow{2}{*}{2} & \multirow{2}{*}{ Keluasan materi } & 2 & 4 & 4 \\
\cline { 3 - 5 } & \multirow{2}{*}{3} & 3 & 4 & 4 \\
\cline { 3 - 5 } & \multirow{2}{*}{ Kedalaman materi } & 4 & 4 & 4 \\
\cline { 2 - 5 } 4 & Akurasi informasi & 6 & 4 & 4 \\
\hline 5 & Akurasi soal & 7 & 4 & 4 \\
\hline 6 & Keterkaitan antar konsep & 8 & 3 & 4 \\
\hline 7 & Pengayaan & 9 & 3 & 4 \\
\hline & & & 34 & 36 \\
\hline
\end{tabular}

Keterangan:

Dengan: $\mathrm{X}=$ Skor yang diperoleh, $\mathrm{Y}=$ skor yang diharapkan

Berdasarkan tabel 1 menunjukkan bahwa jumlah skor hasil validasi ahli materi pembelajaran IPA SD adalah sebesar 34 atau 94\%. Skor tersebut berarti bahwa bahan ajar DELIKAN tematik berbasis multimedia interaktif yang dikembangkan memenuhi kriteria valid dan tidak perlu revisi, sehingga dapat langsung digunakan dalam proses pembelajaran.

Sementara itu, validasi ahli desain bahan ajar DELIKAN tematik berbasis multimedia interaktif dilakukan oleh Ardi Sanjaya, M. Kom. Hasil validasi ahli desain bahan ajar dapat dilihat pada Tabel 2 . 
Tabel 2. Hasil Validasi Ahli Desain Bahan Ajar

\begin{tabular}{|c|c|c|c|c|}
\hline No. & Aspek & Indikator & $\mathbf{X}$ & $\mathbf{Y}$ \\
\hline \multirow[t]{3}{*}{1} & \multirow{3}{*}{$\begin{array}{l}\text { Aspek } \\
\text { Tampilan }\end{array}$} & Desain tampilan bahan ajar & 4 & 5 \\
\hline & & $\begin{array}{l}\text { Tata letak (layout) penempatan gambar pada tampilan } \\
\text { awal bahan ajar }\end{array}$ & 4 & 5 \\
\hline & & Pemilihan desain pada tampilan awal bahan ajar & 4 & 5 \\
\hline \multirow[t]{10}{*}{3} & \multirow{10}{*}{$\begin{array}{l}\text { Aspek } \\
\text { Layout }\end{array}$} & Layout gambar pada isi materi & 5 & 5 \\
\hline & & Pemilihan warna pada gambar & 4 & 5 \\
\hline & & Kesesuaian gambar dengan isi materi & 4 & 5 \\
\hline & & Menumbuhkan rasa ingin tahu & 5 & 5 \\
\hline & & Mendorong informasi lebih jauh & 4 & 5 \\
\hline & & Pemilihan warna pada tulisan & 4 & 5 \\
\hline & & Ukuran huruf dan jenis tulisan & 4 & 5 \\
\hline & & $\begin{array}{l}\text { Gambar motivasi belajar sesuai dengan tujuan dari } \\
\text { pemecahan masalah }\end{array}$ & 4 & 5 \\
\hline & & Komposisi dan kombinasi warna pada tulisan & 4 & 5 \\
\hline & & Dorongan berfikir kritis & 4 & 5 \\
\hline \multirow{3}{*}{4} & \multirow{2}{*}{$\begin{array}{l}\text { Aspek } \\
\text { Ilustrasi }\end{array}$} & $\begin{array}{l}\text { Tata letak (layout) dapat memotivasi siswa untuk } \\
\text { semangat belajar }\end{array}$ & 4 & 5 \\
\hline & & $\begin{array}{l}\text { Komposisi dan kombinasi warna gambar,dengan } \\
\text { tulisan. }\end{array}$ & 4 & 5 \\
\hline & & JUMLAH & 62 & 75 \\
\hline
\end{tabular}

Dengan: $\mathrm{X}=$ Skor yang diperoleh, $\mathrm{Y}=$ Skor maksimum

Tabel 2 menunjukkan bahwa jumlah skor hasil validasi ahli desain bahan ajar adalah sebesar 62 atau 83\%. Hal ini berarti bahwa bahan ajar yang dikembangkan sudah memenuhi kriteria valid dan perlu sedikit revisi dari aspek desain. Revisi yang disarankan oleh ahli desain bahan ajar adalah memperbaiki penulisan huruf, tampilan awal, icon di dalam bahan ajar, dan audio. Bahan ajar DELIKAN tematik berbasis multimedia interaktif yang telah direvisi akan digunakan untuk uji coba skala terbatas.

Sedangkan validasi ahli bahasa untuk bahan ajar DELIKAN tematik berbasis multimedia interaktif dilakukan oleh Encil Puspitaningrum M.Pd. Adapun hasil validasi ahli bahasa sebagaimana tabel 3 .

Tabel 3. Hasil Validasi Ahli Bahasa

\begin{tabular}{lllcc}
\hline No. & \multicolumn{1}{c}{ Aspek } & \multicolumn{1}{c}{ Indikator } & $\mathbf{X}$ & $\mathbf{Y}$ \\
\hline \multirow{2}{*}{$\begin{array}{l}\text { Kesesuaian dengan } \\
\text { Tingkat } \\
\text { Perkembangan } \\
\text { Peserta Didik }\end{array}$} & $\begin{array}{l}\text { Bahasa yang digunakan dalam bahan ajar sesuai } \\
\text { dengan tingkat intelektual siswa }\end{array}$ & 4 \\
\cline { 3 - 5 } & $\begin{array}{l}\text { Bahasa yang digunakan dalam bahan ajar sesuai } \\
\text { dengan kematangan sosial emosional siswa }\end{array}$ & 3 & 4 \\
\hline \multirow{2}{*}{2} & $\begin{array}{l}\text { Pesan dalam bahan ajar disajikan dengan bahasa } \\
\text { Kekomunikativan }\end{array}$ & $\begin{array}{l}\text { yang menarik, tepat sasaran, dan tidak } \\
\text { menimbulkan makna ganda, serta sesuai dengan } \\
\text { komunikasi tulis dalam bahasa Indonesia }\end{array}$ & 4 \\
\cline { 3 - 5 } & Kata dan kalimat yang digunakan mengacu pada & 3 & 4 \\
\hline
\end{tabular}




\begin{tabular}{llcllll}
\hline \multicolumn{6}{l}{ kaidah bahasa Indonesia yang sesuai dengan EYD } \\
\hline 3 & $\begin{array}{l}\text { Keruntutan } \\
\text { Keterpaduan } \\
\text { Pikir }\end{array}$ & Alur & $\begin{array}{l}\text { Penyampaian pesan antar materi dalam satu } \\
\text { subtema mencerminkan hubungan yang logis }\end{array}$ & 3 & 4 \\
\hline & JUMLAH & 16 & 20 \\
\hline
\end{tabular}

Dengan: $\mathrm{X}=$ Skor yang diperoleh, $\mathrm{Y}=$ Skor maksimum

Dari Tabel 3 terlihat bahwa jumlah skor hasil validasi ahli Bahasa untuk bahan ajar DELIKAN adalah sebesar 16 atau 80\%. Hal ini berarti bahwa bahan ajar yang dikembangkan sudah memenuhi kriteria valid dan perlu sedikit revisi dari aspek bahasa. Validator memberikan saran agar kata dan kalimat yang digunakan harus mengacu pada kaidah bahasa Indonesia yang baik dan benar sesuai dengan EYD.

Adapun deskripsi hasil revisi bahan ajar yang dikembangkan sebagaimana tabel 4 berikut:

Tabel 4. Deskripsi Hasil Revisi Bahan Ajar

\begin{tabular}{|c|c|c|}
\hline Aspek & Saran perbaikan & Hasil revisi \\
\hline Materi & $\begin{array}{l}\text { 1. Gambar iklan pada materi } \\
\text { harus sesuai dengan materi } \\
\text { yang sedang dipelajari }\end{array}$ & $\begin{array}{l}\text { 1. Gambar iklan pada materi } \\
\text { diperjelas dan disesuaikan dengan } \\
\text { materi yang sedang dipelajari }\end{array}$ \\
\hline $\begin{array}{l}\text { Desain Bahan } \\
\text { Ajar }\end{array}$ & $\begin{array}{l}\text { 1. Penulisan huruf dan kata } \\
\text { harus baku } \\
\text { 2. Tampilan awal alangkah } \\
\text { baiknya menampilkan info } \\
\text { tentang apa itu DELIKAN } \\
\text { 3. Icon dalam bentuk gambar } \\
\text { kurang } \\
\text { 4. Kualitas audio ditingkatkan }\end{array}$ & $\begin{array}{l}\text { 1. Penulisan huruf dan kata secara } \\
\text { baku } \\
\text { 2. Tampilan awal menampilkan info } \\
\text { tentang apa itu DELIKAN } \\
\text { 3. Penambahan icon dalam bentuk } \\
\text { gambar } \\
\text { 4. Peningkatan kualitas audio }\end{array}$ \\
\hline Bahasa & $\begin{array}{l}\text { 1. Kata dan kalimat yang } \\
\text { digunakan belum mengacu } \\
\text { pada kaidah bahasa } \\
\text { Indonesia yang sesuai } \\
\text { dengan EYD }\end{array}$ & $\begin{array}{l}\text { 1. Kata dan kalimat yang digunakan } \\
\text { dalam bahan ajar DELIKAN } \\
\text { tematik berbasis multimedia } \\
\text { interaktif disesuaikan dengan } \\
\text { kaidah bahasa Indonesia yang } \\
\text { sesuai dengan EYD }\end{array}$ \\
\hline
\end{tabular}

\section{Hasil Uji Kepraktisan Bahan Ajar}

Kepraktisan bahan ajar yang dikembangkan dinilai berdasarkan respon siswa dan guru terhadap proses pembelajaran dengan menggunakan bahan ajar DELIKAN tematik berbasis multimedia interaktif. Adapun data hasil respon siswa dan guru terhadap penggunaan bahan ajar DELIKAN tematik berbasis multimedia interaktif adalah sebagai berikut:

\section{Uji Coba Produk Terbatas (kelompok kecil)}

Uji coba kelompok kecil ini dilakukan setelah bahan ajar DELIKAN tematik berbasis multimedia interaktif selesai divalidasi dan direvisi berdasarkan saran dan 
masukan dari para validator ahli multimedia, ahli materi, dan ahli bahasa. Uji coba kelompok kecil ini akan dilihat kelayakan awal dalam penggunaan bahan ajar DELIKAN tematik berbasis multimdia interaktif. Instrumen yang digunakan untuk mangambil data kelayakan bahan ajar DELIKAN tematik berbasis multimedia interaktif berupa angket yang diberikan pada subjek kelompok kecil. Subjek kelompok kecil yang digunakan adalah 6 siswa kelas V SD.

Tahap kepraktisan pada uji coba terbatas ini berdasarkan respon siswa yang meliputi aspek grafis dan aspek isi. Hasil angket uji coba terbatas dapat dilihat pada Tabel 5.

Tabel 5. Hasil Respon Siswa Terhadap Produk

\begin{tabular}{lll}
\hline No & Nama Siswa & Skor \\
\hline 1 & Fernando Setiawan & 43 \\
\hline 2 & Sifa Nur Churrota & 41 \\
\hline 3 & Ahmad Oksa Muflihin & 40 \\
\hline 4 & Pandji Angga A & 43 \\
\hline 5 & Endra Gavin & 42 \\
\hline 6 & Achmad Saifudin & 40 \\
\hline Rata-rata & $\mathbf{4 2}$ \\
\hline
\end{tabular}

Berdasarkan Tabel 5 terlihat bahwa skor rata-rata respon siswa terhadap penggunaan bahan ajar DELIKAN berbasis multimedia interaktif pada tahap uji coba kelompok kecil adalah sebesar 42 atau 93\%. Skor tersebut termasuk dalam kategori baik, yakni bahan ajar DELIKAN berbasis multimedia interaktif praktis digunakan dalam proses pembelajaran.

\section{Data Uji Coba Produk Utama (Lapangan)}

Uji coba selanjutnya yaitu uji coba lapangan yang dilakukan dengan meminta tanggapan responden dari guru dan 20 siswa. Pengujian ini merupakan pengujian tahap akhir kategori kelayakan/kepraktisan bahan ajar yang dikembangkan. Berikut paparan respon guru dan siswa terhadap penggunaan bahan ajar DELIKAN berbasis multimedia interaktif.

a. Respon guru terhadap penggunaan bahan ajar DELIKAN

Adapun data hasil angket respon guru terhadap penggunaan bahan ajar DELIKAN berbasis multimedia interaktif adalah sebagaimana tabel 6 berikut: 
Tabel 6. Hasil Respon Guru Terkait Kepraktisan Produk

\begin{tabular}{|c|c|c|c|c|c|}
\hline \multirow[t]{2}{*}{ No } & \multirow[t]{2}{*}{ Indikator } & \multicolumn{4}{|c|}{$\begin{array}{c}\text { Skala } \\
\text { penilaian }\end{array}$} \\
\hline & & 1 & 23 & 4 & 5 \\
\hline 1 & Materi mudah dipahami & & & & $\sqrt{ }$ \\
\hline 2 & Kesesuaian materi dengan kondisi siswa & & & & $\sqrt{ }$ \\
\hline 3 & $\begin{array}{l}\text { Penggunaan bahasa yang tepat dalam } \\
\text { menjelaskan materi }\end{array}$ & & & & $\sqrt{ }$ \\
\hline 4 & $\begin{array}{l}\text { Kesesuaian materi pemecahan masalah } \\
\text { dengan } \mathrm{SK} / \mathrm{KD}\end{array}$ & & & & $\sqrt{ }$ \\
\hline 5 & Kesesuaian materi dengan indicator & & & & $\sqrt{ }$ \\
\hline 6 & Kejelasan petunjuk belajar & & & $\sqrt{ }$ & \\
\hline 7 & $\begin{array}{l}\text { Kebenaran uraian materi dengan pemecahan } \\
\text { masalah }\end{array}$ & & & & $\sqrt{ }$ \\
\hline 8 & Kegiatan belajar dapat memotivasi siswa & & & $\sqrt{ }$ & \\
\hline 9 & Pemilihan warna tulisan sudah tepat & & & & $\sqrt{ }$ \\
\hline 10 & Pemberian latihan untuk penambahan materi & & & $\sqrt{ }$ & \\
\hline 11 & Pemilihan gambar menarik motivasi siswa & & & & $\sqrt{ }$ \\
\hline 12 & $\begin{array}{l}\text { Desain tampilan bahan ajar DELIKAN } \\
\text { berbasis multimedia interaktif }\end{array}$ & & & & $\sqrt{ }$ \\
\hline 13 & Ukuran huruf dan jenis tulisan & & & $\sqrt{ }$ & \\
\hline 14 & Kejelasan narasi & & & & $\sqrt{ }$ \\
\hline 15 & Kemudahan penggunaan & & & & $\sqrt{ }$ \\
\hline 16 & Berbasis teknologi & & & & $\sqrt{ }$ \\
\hline 17 & Praktis dalam penerapan & & & & $\sqrt{ }$ \\
\hline 18 & Sesuai dengan kemajuan jaman & & & & $\sqrt{ }$ \\
\hline & Jumlah & & 86 & & \\
\hline
\end{tabular}

Dari tabel 6 terlihat bahwa jumlah skor angket respon guru sebesar 86 atau 96\%. Hal ini berarti bahwa tingkat kepraktisan bahan ajar DELIKAN tematik berbasis multimedia interaktif berdasarkan respon guru mencapai $96 \%$ dengan kategori sangat praktis. Selain mengisi lembar kepraktisan guru juga memberikan tanggapan bahwa bahan ajar DELIKAN tematik berbasis multimedia interaktif sangat cocok untuk pembelajaran anak-anak kelas $\mathrm{V}$, selain menarik bahan ajar DELIKAN tematik berbasis multimedia interaktif ini mudah dipahami sehingga anak dapat belajar secara maksimal.

b. Respon siswa terhadap penggunaan bahan ajar DELIKAN

Data kepraktisan angket siswa disusun berdasarkan 9 indikator, yaitu (1) tampilan bahan ajar, (2) ukuran dan tampilan huruf, (3) kesesuaian gambar, (4) pemilihan warna, (5) kemenarikan produk, (6) kejelasan petunjuk, (7) kejelasan materi, (8) penggunaan bahasa, dan (9) kemudahan materi untuk dipahami. Berikut hasil respon siswa terhadap kepraktisan bahan ajar DELIKAN dapat dilihat pada tabel 7. 
Tabel 7. Hasil Respon Siswa Terkait Kepraktisan Produk

\begin{tabular}{lll}
\hline No & Nama Siswa & Skor \\
\hline 1 & Fernando Setiawan & 43 \\
\hline 2 & Sifa Nur Churrota & 41 \\
\hline 3 & Ahmad Oksa Muflihin & 40 \\
\hline 4 & Pandji Angga A & 43 \\
\hline 5 & Endra Gavin & 42 \\
\hline 6 & Achmad Saifudin & 40 \\
\hline 7 & Amalia Eka Putri P & 42 \\
\hline 8 & Destia dwi Agsya & 44 \\
\hline 9 & Desinta Marta Vania & 43 \\
\hline 10 & Ratih Dwi Nur Habibah & 41 \\
\hline 11 & Alfina Rahmawati & 44 \\
\hline 12 & Imaniar Puji Lestari & 43 \\
\hline 13 & Alva Resty Agustina & 44 \\
\hline 14 & Salsabila Nihayatul & 43 \\
\hline 15 & Ayu Dwi Ariani & 42 \\
\hline 16 & Moh. Janitra Rama A & 44 \\
\hline 17 & Vanila Adela Putri & 43 \\
\hline 18 & Sabitha Resti Rafidah & 44 \\
\hline 19 & Nayla Shifa Az Zahra & 44 \\
\hline 20 & Grecia Pink Destiawati & 43 \\
\hline & Rata-rata & $\mathbf{4 3}$ \\
\hline & &
\end{tabular}

Berdasarkan Tabel 8 terlihat bahwa skor rata-rata respon siswa terhadap penggunaan bahan ajar DELIKAN berbasis multimedia interaktif adalah sebesar 43 atau 95\%. Hal ini berarti bahwa tingkat kepraktisan bahan ajar DELIKAN tematik berbasis multimedia interaktif berdasarkan respon siswa mencapai 95\% dengan kategori sangat praktis.

\section{Hasil Uji Keefetifan Produk}

Keefektifan bahan ajar DELIKAN tematik berbasis multimdia interaktif diperoleh dari hasil belajar siswa menggunakan soal evaluasi yang ada pada bahan ajar bagian quis. Soal evaluasi dalam bahan ajar ini berisi soal-soal yang berkaitan dengan materi pada tema 9 sub tema 1. Adapun data hasil belajar siswa menggunakan bahan ajar DELIKAN adalah sebagaimana tabel 8 . 
Tabel 8. Data Hasil Keefektifan

\begin{tabular}{llll}
\hline No & Nama Siswa & Nilai & Keterangan \\
\hline 1 & Fernando Setiawan & 80 & $\mathrm{~T}$ \\
\hline 2 & Sifa Nur Churrota & 100 & $\mathrm{~T}$ \\
\hline 3 & Ahmad Oksa Muflihin & 80 & $\mathrm{~T}$ \\
\hline 4 & Pandji Angga A & 100 & $\mathrm{~T}$ \\
\hline 5 & Endra Gavin & 90 & $\mathrm{~T}$ \\
\hline 6 & Achmad Saifudin & 60 & $\mathrm{TT}$ \\
\hline 8 & Amalia Eka Putri P & 100 & $\mathrm{~T}$ \\
\hline 9 & Destia dwi Agsya & 60 & $\mathrm{TT}$ \\
\hline 10 & Ratih Dwi Nur Habibah & 80 & $\mathrm{~T}$ \\
\hline 11 & Alfina Rahmawati & 80 & $\mathrm{~T}$ \\
\hline 12 & Imaniar Puji Lestari & 100 & $\mathrm{~T}$ \\
\hline 13 & Alva Resty Agustina & 80 & $\mathrm{~T}$ \\
\hline 14 & Salsabila Nihayatul & 100 & $\mathrm{~T}$ \\
\hline 15 & Ayu Dwi Ariani & 70 & $\mathrm{TT}$ \\
\hline 16 & Moh. Janitra Rama A & 100 & $\mathrm{~T}$ \\
\hline 17 & Vanila Adela Putri & 100 & $\mathrm{~T}$ \\
\hline 18 & Sabitha Resti Rafidah & 100 & $\mathrm{~T}$ \\
\hline 19 & Nayla Shifa Az Zahra & 100 & $\mathrm{~T}$ \\
\hline 20 & Grecia Pink Destiawati & 100 & $\mathrm{~T}$ \\
\hline Rata-rata & 89 & \\
\hline Siswa yang tuntas & & 17 \\
\hline Siswa yang tidak tuntas & & 3 \\
\hline
\end{tabular}

Tabel 8 menunjukkan bahwa rata-rata hasil belajar siswa sebesar 89 dengan jumlah yang tuntas sebanyak 17 siswa dan siswa yang belum tuntas sebanyak 3 siswa. Hal ini berarti bahwa prosentase ketuntasan hasil belajar siswa mencapai $85 \%$ dengan kategori sangat efektif. Keefektiffan bahan ajar DELIKAN sudah mencapai di atas kriteria ketuntasan minimum (KKM). KKM yang ditentukan untuk siswa yaitu 75 untuk setiap induvidu dan ketuntasan klasikal adalah 75\%. Berdasarkan hasil analisis data hasil belajar keefektifan bahan ajar DELIKAN tematik berbasis multimdia interaktif sangat efektif untuk siswa SD kelas V.

\section{PEMBAHASAN}

Dalam penelitian dan pengembangan ini menghasilkan sebuah produk bahan ajar DELIKAN tematik berbasis multimedia interaktif untuk siswa kelas V sekolah dasar pada tema 9 sub tema 1 (benda tunggal dan campuran). Produk bahan ajar DELIKAN tematik berbasis multimedia interaktif ini disimpan dalam bentuk $\mathrm{CD}$ dengan format exe, dengan tujuan agar produk ini dapat digunakan dengan mudah untuk menampilkan animasi, gambar, audio, dan vidio sebagai pendukung di dalamnya. Sejalan dengan pendapatnya (Darmawan, 2012) bahwa 
pembelajaran multimedia itu memiliki karakteristik berupa konten materi yang representatif dalam bentuk visual, gambar, animasi, audio, memiliki kekuatan warna dan tipe-tipe pembelajaran yang bervariasi.

Berdasarkan hasil analisis validitas produk dalam penggunaan bahan ajar DELIKAN tematik berbasis multimedia interaktif terhadap uji coba lapang ditinjau dari ahli materi, ahli bahan ajar, dan ahli bahasa dapat diketahui bahwa analisis validitas untuk ahli materi mendapatkan skor sebesar 94\% dengan kategori valid tanpa revisi. Sedangkan untuk ahli bahan ajar dari hasil analisis data didapatkan skor sebesar $83 \%$ dengan kategori valid tanpa revisi. Untuk ahli bahasa didapatkan data sebesar $80 \%$ dengan kategori valid tanpa revisi. Berdasarkan hasil analisis data dari ketiga validator yaitu ahli materi, ahli bahan ajar, dan ahli bahasa dapat dinyatakan bahwa bahan ajar DELIKAN tematik berbasis multimedia interaktif valid dan dapat digunakan dalam pembelajaran siswa SD kelas V. Didukung oleh pendapat (Munadi, 2013) yang menyatakan bahwa kelebihan multimedia interaktif yaitu siswa diajak untuk terlibat secara auditif, visual, dan kinetik sehingga dimungkinkan informasinya mudah dimengerti.

Produk ini dikatakan praktis berdasarkan hasil uji coba lapang berdasarkan respon guru dan siswa kelas V. Dari hasil respon siswa didapatkan hasil rata-rata siswa mencapai 93\% pada tahap uji coba terbatas dan tahap uji coba lapangan skor kepraktisan dari 20 siswa yaitu $95 \%$ dengan kategori sangat praktis. Sedangkan berdasarkan respon guru mendapatkan hasil $96 \%$ dengan kategori sangat praktis. Hasil respon guru dilihat berdasarkan aspek pembelajaran, kegrafisan, dan aspek penggunaan. Selain itu guru juga memberikan komentar didalam angket tersebut dengan menyatakan bahwa bahan ajar DELIKAN tematik berbasis multimedia interaktif sangat cocok untuk pembelajaran anak-anak kelas V selain menarik, mudah dipahami sehingga anak belajar secara maksimal. Berdasarakan data tersebut dapat dinyatakan bahwa bahan ajar DELIKAN tematik berbasis multimdia interaktif sangat praktis untuk siswa SD kelas V. (Nieveen, 2010) menyatakan bahwa produk yang dikembangkan dikatakan praktis jika pengguna (guru dan siswa) menyatakan produk mudah digunakan.

Produk bahan ajar DELIKAN tematik berbasis multimdia interaktif yang telah dikembangkan ini juga dinyatakan efektif karna memberikan dampak yang positif terhadap hasil belajar siswa. Keefektifan produk tersebut dibuktikan dengan prosentase ketuntasan hasil belajar siswa yang mencapai $85 \%$ dengan kategori sangat efektif. Keefektiffan bahan ajar sudah mencapai diatas kriteria ketuntasan minimum (KKM). Berdasarkan data analisis keefektiffan siswa diketahui dari 20 siswa 17 siswa telah memperoleh nilai diatas KKM yang telah ditentukan. KKM yang ditentukan untuk siswa yaitu 75 untuk setiap induvidu dan ketuntasan klasikal adalah 75\%. Sesuai dengan pendapat (Smaldiono, 2011) yang menyatakan bahwa kelebihan dari multimedia interaktif ini yaitu memungkinkan siswa secara individu 
mengendalikan laju dan urutan pembelajaran yang memberikan banyak kontrol atas hasil belajar. Hasil penelitian ini juga didukung oleh hasil penelitiannya Tüzün, Yılmaz-Soylu, Karakus, İnal \& Kizılkaya (2009), Zhang \& Zhou (2003), Surjono \& Susila (2013), Juanda (2012), Smith \& Woody (2000), Maharani (2015), Zhang, Zhou, Briggs \& Nunamaker (2006) dalam penelitiannya menyimpulkan bahwa penggunaan media pembelajaran interaktif dinilai dapat meningkatkan motivasi dan hasil belajar siswa, baik aspek afektif maupun aspek kognitif. Dengan demikian dapat dinyatakan bahwa bahan ajar DELIKAN tematik berbasis multimdia interaktif sangat efektif untuk siswa SD kelas V.

\section{KESIMPULAN}

Berdasarkan analisis hasil penelitian yang telah dikemukakan dapat disimpulkan: 1) Validitas produk bahan ajar DELIKAN tematik berbasis multimedia interaktif memenuhi kriteria valid berdasarakan ahli materi 94\%, ahli bahan ajar $83 \%$, ahli bahasa $80 \%$, serta dapat digunakan dalam pembelajaran siswa SD kelas V. 2) Kepraktisan produk bahan ajar DELIKAN tematik berbasis multimedia interaktif berdasarkan respon siswa mencapai 95\% dan respon guru sebesar 96\% memberikan tanggapan yang baik dengan memberikan komentar bahwa bahan ajar DELIKAN tematik berbasis multimedia interaktif sangat cocok untuk pembelajaran anak-anak kelas V selain menarik, mudah dipahami, sehingga anak belajar secara maksimal. 3) Keefektifan dilihat berdasarkan ketuntasan hasil belajar siswa mencapai $85 \%$ dengan kategori sangat efektif. Keefektiffan bahan ajar sudah mencapai diatas kriteria ketuntasan minimum (KKM). Sesuai dengan simpulan hasil penelitian, saran yang dapat disampaikan yaitu: 1) Bahan ajar DELIKAN tematik berbasis multimedia interaktif dapat dijadikan salah satu alternatif dalam proses pembelajaran siswa. 2) Sekolah hendaknya mensosialisasikan bahan ajar DELIKAN tematik berbasis multimedia interaktif kepada semua guru.

\section{DAFTAR PUSTAKA}

Ali, M. (2009). Pengembangan Media Pembelajaran Interaktif Mata Kuliah Medan Elektromagnetik. Jurnal Edukasi: Elektro, 5(1), 11-18.

Arief, F. (2013). Globalisasi Pendidikan, (Online), (http://edukasikompasiana. com/2011/06/08/ globalisasi-pendidikan-371426. html).

Borg, W. R. \& Gall, M.D. (1987). Educational Research. An Introduction (4th ed.). New York: Longman Inc.

Darmawan, D. (2012). Pendekatan Praktik Teknologi Multimedia dan Pembelajaran Online. Bandung: PT. Remaja Rosdakarya. 
Fibriani, L., Damris, M., \& Risnita. (2014). Pengembangan Multimedia Interaktif untuk Meningkatkan Motivasi dan Hasil Belajar Siswa pada Materi Kesetimbangan Kimia SMA. Jurnal Edu-Sains, 3(1), 1-5.

Hardianto, D. (2013). Telaah Kritis Pemanfaatan Teknologi Komputer Dalam Pembelajaran, (Online),(http://staff.uny.ac.id/sites/default/files/penelitian/Deni/Hardianto/M.Pd./Telaah /Kritis/Pemanfaatan/Teknologi/Komputer/Dalam/Pembelajaran.pdf),

Juanda, E. A. (2012). Media Pembelajaran Berbasis Multimedia Interaktif Untuk Meningkatkan Pemahaman Dasar-Dasar Mikrokontroler. Jurnal Ilmu Pendidikan, 17(6),

Komalasari, K. (2010). Pembelajaran Kotekstual Konsep dan Aplikasi. Bandung: PT Refika Aditama.

Lee, W. W. \& Owens, D. L. (2004). Multimedia-Based Instructional Design. San Francisco: Pleiffer

Maharani, Y. S. (2015). Efektivitas Multimedia Pembelajaran Interaktif Berbasis Kurikulum 2013. Indonesian Journal of Curriculum and Educational Technology Studies, 3(1), 3140

Munadi, Y. (2013). Media Pembelajaran,Sebuah Pendekatan Baru. Jakarta: Referensi (GP Press Group).

Nieveen, N., Mc Kenney, S., \& Akker, J.V.D. (2006). Educational Design Research: The Value of Variety. Dalam Akker, J.V.D., Gravemeijer, K., McKenney, S., \& Nieveen, N (Eds.), Educational Design Research (hlm. 144-184). Enchede: Axis Media-ontwerpens.

Nopriyanti \& Sudira, P. (2015). Pengembangan Multimedia Pembelajran Interaktif Kopetensi Dasar Pemasangan Sistem Penerangan dan Wiring Kelistrikan di SMK. Jurnal Pendidikan Vokasi, 5(2), 222 - 235.

Smaldino, S. E. dkk. (2011). Teknologi Pembelajaran dan Media untuk Belajar (edisi 9). Jakarta: Kencana Prenada Media Group.

Smaldino, S. E., Lowther, D. L., Russel, J.D. (2011). Teknologi Pembelajaran dan Media untuk Belajar. (Alih Bahasa: Arif Rahman). Jakarta: KENCANA.

Smith, S. M. \& Woody, P. C. (2000). Interactive Effect of Multimedia Instruction and Learning Styles. Teaching of Psychology, 27(3), 220-223

Surjono, H.K. \& Susila, H.R. (2013). Pengembangan Multimedia Pembelajaran Bahasa Inggris untuk SMK. Jurnal Pendidikan Vokasi, 3(1), 45 - 52.

Tüzün, H., Yılmaz-Soylu, M., Karakuş, T., İnal Y., \& Kizilkaya, G. (2009). The Effects of Computer Games on Primary School Students' Achievement and Motivation in Geography Learning. Computers \& Education, 52(1), 68-77

Zhang, D. \& Zhou, L. (2003). Enhancing E-Learning with Interactive Multimedia," Information Resources Management Journal (IRMJ), 16(4), 1-14.

Zhang, D., Zhou, L., Briggs, R. O. \& Nunamaker Jr, J. F. (2006). Instructional Video in ELearning: Assessing the Impact of Interactive Video on Learning Effectiveness. Information \& Management, 43(1), 15-27. 